\title{
Seed quality of crambe (Crambe abyssinica Hochst) submitted to different drying methods ${ }^{1}$
}

\author{
Qualidade de sementes de crambe (Crambe abyssinica Hochst) submetidas a \\ diferentes métodos de secagem
}

\author{
Magnun Antonio Penariol da Silva², Juliana Joice Pereira Lima ${ }^{3 *}$, Marco Antonio Martin Biaggioni², Claudio \\ Cavariani $^{3}$ and Gisela Ferreira ${ }^{4}$
}

\begin{abstract}
The objective of this research was to evaluate the effects of different drying methods on physiological quality of crambe seeds. Crambe seeds of FMS Brilhante cultivar were produced in the Lageado experimental farm (UNESP, Botucatu, Brazil) in 2012. The drying methods were: artificial drying with hot air, artificial drying with fresh air, natural yard drying, natural shade drying and natural field drying. The water content of seeds was monitored before, during and after drying. Germination, first germination count, abnormal seedlings, GSI, germination synchronization, frequency and germination mean time, electrical conductivity, fatty acid index and oil content were evaluated in order to know the physiological quality. The experimental design was randomized and the averages compared by the t-test at 5\% significance. Results showed that artificial hot air drying favored with higher germination and vigor of crambe seeds when compared to other drying methods and demanded shorter time to reduce the water content. The natural shade drying method is feasible for crambe seeds despite taking longer.
\end{abstract}

Key words: Natural drying. Artificial drying. Crambe seeds vigor. Seeds damage.

RESUMO - Objetivou-se nesta pesquisa avaliar o efeito de diferentes métodos de secagem na qualidade fisiológica de sementes de crambe. As sementes de crambe da cultivar FMS Brilhante foram produzidas na Fazenda Experimental Lageado (UNESP - Botucatu) no ano de 2012. As condições de secagem foram: secagem artificial com ar aquecido, secagem artificial com ar natural, secagem natural em terreiro, secagem natural à sombra e secagem na planta. $\mathrm{O}$ teor de água foi monitorado antes, durante e após a secagem. Para avaliação da qualidade fisiológica foi realizado o teste de germinação, primeira contagem de germinação, plântulas anormais, IVG, sincronização da germinação, frequência e tempo médio de germinação, teste de condutividade elétrica, índice de acidez graxa e teor de óleo. O delineamento experimental foi inteiramente casualizado e as médias comparadas pelo teste de Tukey a 5\% de significância. Pelos resultados obtidos a secagem artificial com alta temperatura favoreceu obtenção de sementes de crambe com alta germinação e vigor em relação aos demais tipos de secagem com um tempo menor para redução do teor de água. A secagem natural na sombra é viável para sementes de crambe apesar de ser longa.

Palavras-chave: Secagem natural. Secagem artificial. Vigor de sementes de crambe. Danos em sementes.

\footnotetext{
DOI: $10.5935 / 1806-6690.20160042$

*Autor para correspondência

${ }^{1}$ Recebido para publicação em 29/11/2013; aprovado em 10/11/2015

Parte da Dissertação de Mestrado do primeiro autor apresentada ao Programa de Pós-Graduação em Energia na Agricultura da Universidade Estadual Paulista "Júlio de Mesquita Filho

${ }^{2}$ Departamento de Engenharia Rural, Faculdade de Ciências Agronômicas, Universidade Estadual Paulista Júlio de Mesquita Filho, BotucatuSP, Brasil, 18.610-307, penariol@gmail.com, biaggioni@fca.unesp.br

${ }^{3}$ Departamento de Produção e Melhoramento Vegetal, Faculdade de Ciências Agronômicas, Universidade Estadual Paulista Júlio de Mesquita Filho, Rua José Barbosa de Barros, 1780, Caixa Postal 237, Botucatu-SP, Brasil, 18.610-307. julianajoicelima@yahoo.com.br, ccavariani@fca.unesp.br

${ }^{4}$ Instituto de Biociências, Universidade Estadual Paulista Júlio de Mesquita Filho, Botucatu-SP, Brasil, gisela@ibb.unesp.br
} 


\section{INTRODUCTION}

Member of the Brassicaceae family, crambe (Crambe abyssinica Hostch) is a annual cycle plant species and it is tolerant to drought and cold conditions. In the climatic conditions of Brazil it is cultivated in wintertime. The great interest in this specie is due to the high seed oil and protein concentrations plus its agronomic advantages such as reduced demand for crop treatment, satisfactory yield (around $1500 \mathrm{~kg} / \mathrm{ha}$ ) and short cycle (90 days), makes it a potential raw material for biodiesel production (MASETTO et al., 2009; MASETTO et al., 2011; PITOL, 2008; SOUZA et al., 2009).

Crambe has been gaining more importance in recent years, however, there is not much information in the literature about seed production with high physiological quality. To obtain the desired seed quality care must be taken at all stages of the production process, particularly in the harvest, processing, and storage.

Seeds with high water content may have their quality affected by mechanical damages suffered during improvement processes, moreover performance and separation efficiency of the machines used also can influence the physiological quality (CARVALHO; NAKAGAWA, 2012). This makes drying a critical process in this production stage.

Drying allows harvesting to near physiological maturity when water content and quality are high. Its goal is to reduce the water content of the seeds to levels adequate to storage, preserving them from physical and chemical changes induced by excess water (RESENDE et al., 2012). However, because the removal of water during seed drying can cause chemical, physical and biological changes, the drying conditions must be monitored so that all possible effects on seed quality have to be considered (JOSÉ et al., 2005; ROSA et al., 2005).

The drying methods are chosen according to the characteristics of species, the quantity of seed and the weather conditions likely to prevail after harvest (FRANKE; TORRES; LOPES, 2008) and can be classified as natural or artificial. Natural drying employs air, without modification of its characteristics, and sun to reduce the water content of the seeds in the field, on a yard or in sheds (GARCIA et al., 2004). Depending on the species, seeds can be attached or not to the plant or even remain inside of the fruits. The artificial drying method is characterized by forced air through seed mass (ZUCHI et al., 2009).

Baker, Paulsen and Van-Zweden (1991) and Donadon et al. (2013) mention that decrease of germination is due to damaged cell membranes or disorganization of cell components when drying is on high temperatures. Costa et al. (2012a) studied the effect of artificial drying with air at different temperatures on the physiological quality of crambe seeds and they did not observe effects on germination for the temperature used $\left(35-90{ }^{\circ} \mathrm{C}\right)$. Costa et al. (2012b), studying the same species but at drying with temperature from 23 to $70^{\circ} \mathrm{C}$, observed higher germination when the seeds were dried at $30^{\circ} \mathrm{C}$.

Given the importance of drying, the objective of this research was to evaluate the effects of different drying methods on the physiological quality of the crambe seeds.

\section{MATERIAL AND METHODS}

Crambe seeds of FMS Brilhante cultivar developed by the Fundação MS were produced in the winter of the crop year 2012 in the Lageado agricultural experimental farm, Faculdade de Ciências Agronômicas, UNESP - Univ Estadual Paulista, with the following coordinates and geographic characteristics: $22^{\circ} 52^{\prime} 20^{\prime \prime} \mathrm{S}$ and $48^{\circ} 26^{\prime} 37^{\prime \prime} \mathrm{W}$, average altitude of 770 meters, an average slope of $4.5 \%$ and a subtropical climate with warm, wet summers and cool dry winter. Fertilization followed Oliva, Biagnoni and Cavariani (2012) and was preceded by soil analysis. Sowing was made in May and harvesting in August 2012. Evaluations were performed in the Agricultural Products Processing Laboratory of the Rural Engineering Department and in the Laboratory of Seed Analysis of the Production and Plant Breeding Department.

Water content of seeds was monitored before, during and after drying, employing the oven at $105 \pm 3{ }^{\circ} \mathrm{C}$ method (BRASIL, 2009), with three replicates and its results were given as the wet basis percentage. Drying was finished when the seeds reached $8.0 \pm 2.0 \%$ of water content. Water content of seeds during the drying was estimated based on the weight and water content initial. The following drying methods were used:

Fixed artificial drying with hot air: it was carried out in a research dryer developed at FCA UNESP made of PVC columns $0.8 \mathrm{~m}$ high and $0.15 \mathrm{~m}$ in diameter and with a metal screen at its bottom. The height of the seed mass was 0.60 meters and the drying air blown by a fan driven by an electric motor. The air was heated by an electrical resistance up to a maximum temperature of $60{ }^{\circ} \mathrm{C}$ at the seed mass and monitored by digital thermometers located at $0.10 \mathrm{~m}$ and $0.25 \mathrm{~m}$ from the base of the drying column. The average speed of drying air was measured at the exit of the column with a propeller anemometer and used to compute the average flow of drying air. After the drying the seeds were homogenized to start the analysis.

Fixed artificial drying with natural air: it was carried out in a research dryer developed at FCA - UNESP, 
consisting of PVC columns $1.5 \mathrm{~m}$ high and $0.15 \mathrm{~m}$ in diameter and with a metal screen at its bottom. The height of the seed mass in each column was $1.25 \mathrm{~m}$. Drying air and temperatures of seeds mass were monitored during the drying operations by digital thermometers respectively installed in the inlet air duct and in the drying columns at $0.35 \mathrm{~m}$ and $0.75 \mathrm{~m}$ from their bases. After the drying the seeds are homogenized to start the analysis.

Natural sun yard drying: the seeds were spread over shade screens in a single layer with $5 \mathrm{~cm}$ of height. The seed layer was revolved several times during the day for the better exposure to the sun and by twilight stacked and covered with plastic canvas.

Natural shade drying: the seeds were spread over shade screens in a single layer of one seed of heigt and kept on a shed with natural ventilation.

Natural field drying: the fruits were naturally dried on the plant until their water contents reaches at $8.0 \pm 2.0 \%$.

The evaluation of the physiological quality of seeds was performed using the following tests or evaluations: Germination test conducted with four replicates of 50 seeds for each treatment. Seeds were placed on blotting paper moistened with a solution of potassium nitrate $\left(\mathrm{KNO}_{3}\right)$ at $0.2 \%$ in an amount 2.5 times from mass of the dry substrate and stored in transparent plastic boxes $(11 \mathrm{x}$ $11 \times 3.5 \mathrm{~cm}$ ) and then placed into B.O.D. germinators at a constant temperature of $25^{\circ} \mathrm{C}$. Counts of normal seedlings for subsequent expression of results in percentages were performed on the fourth (first germination count) and seventh days after the test and included the count of abnormal seedlings according to Brasil (2009). Along the germination test, germinated seeds were counted daily in order to calculate the germination speed index (GSI), employing the formula proposed by Maguire (1962).

$\mathrm{GSI}=\mathrm{E}_{1} / \mathrm{N}_{1}+\mathrm{E}_{2} / \mathrm{N}_{2}+\ldots+\mathrm{E}_{\mathrm{m}} / \mathrm{N}_{\mathrm{n}}$

Where: $\mathrm{E}_{1}, \mathrm{E}_{2}, \ldots$, and $\mathrm{E}_{\mathrm{m}}=$ number of seedlings, computed in the first, second, ..., last count and $\mathrm{N}_{1}$, $\mathrm{N}_{2}, \ldots, \mathrm{N}_{\mathrm{n}}=$ number of days from sowing at the first, second, ..., last count.

The Germination Mean Time (GMT), Germination Relative Frequency (RF) and Germination Synchronization (U) were computed according to Labouriau (1983) as follows:

$\mathrm{GMT}=(\Sigma$ niti $) / \Sigma \mathrm{ni}$

Where: GMT = germination mean time; $\mathrm{ni}=$ number of germinated seeds per day; $\mathrm{t} i=$ incubation time (days)

$\mathrm{RF}=\mathrm{ni} / \Sigma \mathrm{ni}$
Where: $\mathrm{RF}=$ relative frequency of germination; ni $=$ number of germinated seeds per day; $\Sigma$ ni $=$ total number of germinated seeds

$\mathrm{U}=-\Sigma \mathrm{fi} \log _{2} \mathrm{fi}$

Where: $\mathrm{U}=$ germination synchronization; fi = relative frequency of germination; $\log _{2}=\log$ arithm base 2 .

The electrical conductivity test was performed according to Vieira and Krzyzanowski (1999), using four replicates of 50 seeds wich mass was determined with a $0.001 \mathrm{~g}$ precision scale, moistened in plastic containers with $75 \mathrm{ml}$ of deionized distilled water which were placed in a B.O.D. incubator at $25{ }^{\circ} \mathrm{C}$ for 24 hours. Electrical conductivity of the solution was determined by a Digimed DM-31 conductivimeter and the average values per gram of moistened seeds were computed in $\mu \mathrm{S} \mathrm{cm}^{-1} \cdot \mathrm{g}^{-1}$. The oil content was determined by the chemical solvent extraction method (Soxhlet). The content of fatty acids was determined as recommended by AACC (1995) and calculated by the equation:

$\mathrm{FA}=$ volume of $\mathrm{KOH} /$ weight of dry sample.

The experimental design was completely randomized. The homogeneity of the data (Shapiro-Wilk test) was verified and then an analysis of variance (F test) was carried out with averages compared by the t-test at $5 \%$ significance level.

\section{RESULTS AND DISCUSSION}

Table 1 is a summary of the analysis of variance for the variables analyzed. According to the $\mathrm{F}$ test at 5\% probability, significant differences were found among treatments for all response variables evaluated.

Table 2 shows the mean percentage of seeds water content before and after drying and the time in hours to reduce them from $20.0 \pm 1.0$ to $8.0 \pm 2.0$ (\% wb). As expected, the shortest time required to reduce the water content of crambe seeds ( 7.4 hours) was observed when employing artificial drying with hot air. The fact is due to the drying air temperature $\left(55.6{ }^{\circ} \mathrm{C}\right)$ which combined with low relative humidity and air flow determined the efficiency of the process (GARCIA et al., 2004).

On the other hand, removing seed water content through natural drying by air and sun weather dependent actions are a slow methods. Depending on the type of natural drying, it took 92,90 or 74 hours to reduce the water content of the seeds to levels comparable to the seeds storage respectively undergoing shade, field and yard. 
Thus, artificial air drying was more than 12 times faster than other drying methods and highlights the relevance of temperature rise and consequent reduction in relative humidity to decrease the drying time with forced air. Zonta et al. (2011) compared various drying methods and Sirisomboon and Kitchaiya (2009), Ahrens et al. (1995) and Ullmann et al. (2010) evaluating the artificial drying in the temperature range from 40 to $80^{\circ} \mathrm{C}$ obtained similar results with jatropha seeds.

The average values of the air temperature in the inlet duct, the relative humidity and air flow recorded with artificial drying with hot and natural air are presented in
Table 3. In the drying with hot air, the average temperature of the drying air duct inlet was $55.6^{\circ} \mathrm{C}$, while the temperature of seed mass was $47{ }^{\circ} \mathrm{C}$ and the air flow $17.6 \mathrm{~m}^{3} \mathrm{~m}^{2} \cdot \mathrm{min}$. Although the air flow was similar in both methods, temperature combined with low humidity made the hot air method the most effective in reducing the humidity of the seed mass.

In the Table 4 is the average results observed in germination and vigor tests. Natural drying of seeds in the field was harmfull for crambe seeds germination and germination speed which is related to the seed vigor tests given by the first germination count and GSI.

Table 1 - Summary of analysis of variance for Germination, First germination count, Abnormal seedlings, Germination synchronization, Germination speed index, Electrical conductivity, Fatty acids and Oil content

\begin{tabular}{lcc}
\hline \multicolumn{1}{c}{ Variables analyzed } & Mean squares & Coefficient of variation $(\%)$ \\
\hline Germination & $216.20^{*}$ & 5.29 \\
First germination count & $1601.3^{*}$ & 5.81 \\
Abnormal seedlings & $62.50^{*}$ & 16.60 \\
Germination synchronization & $0.016^{*}$ & 8.14 \\
Germination speed index & $16.41^{*}$ & 4.67 \\
Electrical conductivity & $6561.2^{*}$ & 5.00 \\
Fatty acids & $4.17^{*}$ & 17.86 \\
Oil content & $39.13^{*}$ & 6.13 \\
\hline
\end{tabular}

*Significant at $5 \%$ probability by $\mathrm{F}$ test

Table 2 - Initial and final mean values of water content (\% wb) and drying time (DT) in crambe seeds in different drying conditions

\begin{tabular}{lccc}
\hline \multirow{2}{*}{ Treatment } & \multicolumn{2}{c}{ Water content $(\% \mathrm{wb})$} & \multirow{2}{*}{ DT (hours) } \\
\cline { 2 - 4 } & Initial & Final & 7.4 \\
\hline Hot air drying & 21.2 & 9.49 & 88 \\
Natural air drying & 21.0 & 6.12 & 74 \\
Natural yard drying & 21.4 & 6.01 & 92 \\
Natural shade drying & 21.3 & 6.85 & 90 \\
Natural field drying & 21.5 & 7.43 & \\
\hline
\end{tabular}

Table 3 - Mean values of the temperatures of the drying air and the seed mass, relative humidity (RH) and air flow when drying crambe seeds with hot air and natural air

\begin{tabular}{|c|c|c|c|c|}
\hline \multirow{2}{*}{ Treatment } & \multicolumn{2}{|c|}{----------------Temperature $\left({ }^{\circ} \mathrm{C}\right)$---------------- } & \multirow{2}{*}{$\mathrm{RH}(\%)$} & \multirow{2}{*}{ Airflow $\left(\mathrm{m}^{3} \mathrm{~min} \bullet \mathrm{m}^{2}\right)$} \\
\hline & Drying air & Seed mass & & \\
\hline Hot air drying & 55.6 & 47.4 & 10.11 & 17.6 \\
\hline Natural air drying & 27.0 & 24.0 & 50.2 & 15.55 \\
\hline
\end{tabular}


Table 4 - Mean values of germination percentage (G), first germination count (FC), abnormal seedlings (A), germination synchronization (U) and germination speed index (GSI) of crambe seeds submitted to different drying conditions

\begin{tabular}{|c|c|c|c|c|c|}
\hline \multirow{2}{*}{ Treatment } & $\mathrm{G}$ & $\mathrm{FC}$ & $\mathrm{A}$ & $\mathrm{U}$ & \multirow{2}{*}{ GSI } \\
\hline & ------------. & ------- & ------- & -------------- & \\
\hline Hot air drying & $80 \mathrm{a}$ & $72 \mathrm{a}$ & $07 \mathrm{a}$ & $1.63 \mathrm{a}$ & $12.84 \mathrm{a}$ \\
\hline Natural air drying & $73 \mathrm{~b}$ & $53 \mathrm{c}$ & $13 \mathrm{~b}$ & $2.03 b c$ & $11.05 \mathrm{c}$ \\
\hline Natural yard drying & $78 \mathrm{ab}$ & $53 \mathrm{c}$ & $16 \mathrm{e}$ & $2.01 \mathrm{c}$ & $11.91 \mathrm{~b}$ \\
\hline Natural shade drying & $84 \mathrm{a}$ & $64 \mathrm{~b}$ & $11 \mathrm{~b}$ & $1.83 \mathrm{ab}$ & $12.57 \mathrm{ab}$ \\
\hline Natural field drying & $65 \mathrm{c}$ & $19 \mathrm{~d}$ & $07 \mathrm{a}$ & $1.89 \mathrm{bc}$ & $7.83 \mathrm{~d}$ \\
\hline
\end{tabular}

*Means followed by the same letter do not differ at $5 \%$ level of significance by the t-test

Despite both being natural methods, leaving seeds to dry in the plant resulted in germination approximately $20 \%$ below that obtained with natural shade drying which might be explained by the longer time that seed remains in the field which promotes deterioration and consequent reduction in seed germination. This was also observed in other species such as beans (AHRENS; LOLLATO, 1995), soybean (MIRANDA; SILVA; CAVARIANI, 1999); ryegrass (EICHELBERGER et al., 2003) and jatropha (ZONTA et al., 2011).

Higher values of germination and germination speed index (Table 4) were observed when in the artificial drying with hot air and the natural shade drying methods. Also, a high percentage of normal seedlings in the first germination count and better germination synchronization were seen when crambe seeds were dried on hot air drying. Drying air temperature was approximately $55{ }^{\circ} \mathrm{C}$ and it did not immediately affect seed quality, agreeing with Costa et al. (2012a) but contradicting results found by Costa et al. (2012b), who reported that temperatures close to $60{ }^{\circ} \mathrm{C}$ is detrimental to the germination of crambe seeds. Zonta et al. (2011) and Ullmann et al. (2010) found no effect of drying temperatures respectively of $43{ }^{\circ} \mathrm{C}$ and $60{ }^{\circ} \mathrm{C}$ on the germination of Jatropha seeds.

Artificial drying with natural air and natural yard drying (Table 4) provided an intermediate level of seed germination and vigor. However, the germination synchronization - which measures the organization of a system and whose value varies inversely with organization and synchrony (NASSIF; PEREZ, 2000) for natural yard drying showed greater disorganization of the system although it is not statistically different from artificial drying with natural air and natural field drying. Carvalho and Carvalho (2009) report that the germination synchronization is correlated to germination and germination speed index, similarly to what was observed in this study.
Germination relative frequency (Fr) of crambe seeds versus drying methods shows that the germination mean time (TM) required to reach $60 \%$ of seed germination under hot air drying was 3.67 days (Figure 1), which demonstrates the superior vigor of these method. In a similar manner, the artificial drying with natural air and the natural yard drying methods demanded longer periods before most seeds germinated (4.28 and 4.38 days). However, seed damaged was most noticed for the natural field drying method.

Reductions in seed physiological quality are generally accompanied by increased electrolyte and sugar liberation by water soaked seeds as a result of loss of selective permeability of the cell membranes (VIEIRA, 1994). The damage causes by drying to the membrane system can be estimated by measuring electrical conductivity. Table 5 shows a lower electrical conductivity of the soaking solution when the seeds were dried naturally in the field which, however, it was the drying method most damaging to seed germination and vigor. There were no significant differences in the electrical conductivity of crambe seed leachate subjected to the other drying methods.

Sensitivity is the main advantage of the fatty acid test method for assessing the deterioration of stored seeds. Formation of free fatty acids in the seed results from the hydrolysis of lipids and the lipids acidity test can detect the onset of the deterioration process (BIAGGIONI; BARROS, 2006). The results for the lipids acidity index (Table 5) shows the superiority of artificial hot air drying when compared to the other methods evaluated regarding the production of crambe seeds of better quality. However, the test was not sensitive enough to distinguish the other treatments regarding vigor levels.

Assessing the oil quality obtained from these seeds from each drying method, the highest seed oil 
Figure 1 - Germination Relative Frequency (RF) of crambe seeds submitted to different drying methods. PG: average percentage of germinated seeds and GMT: Germination Mean Time (days). Arrows indicate the Germination Mean Time
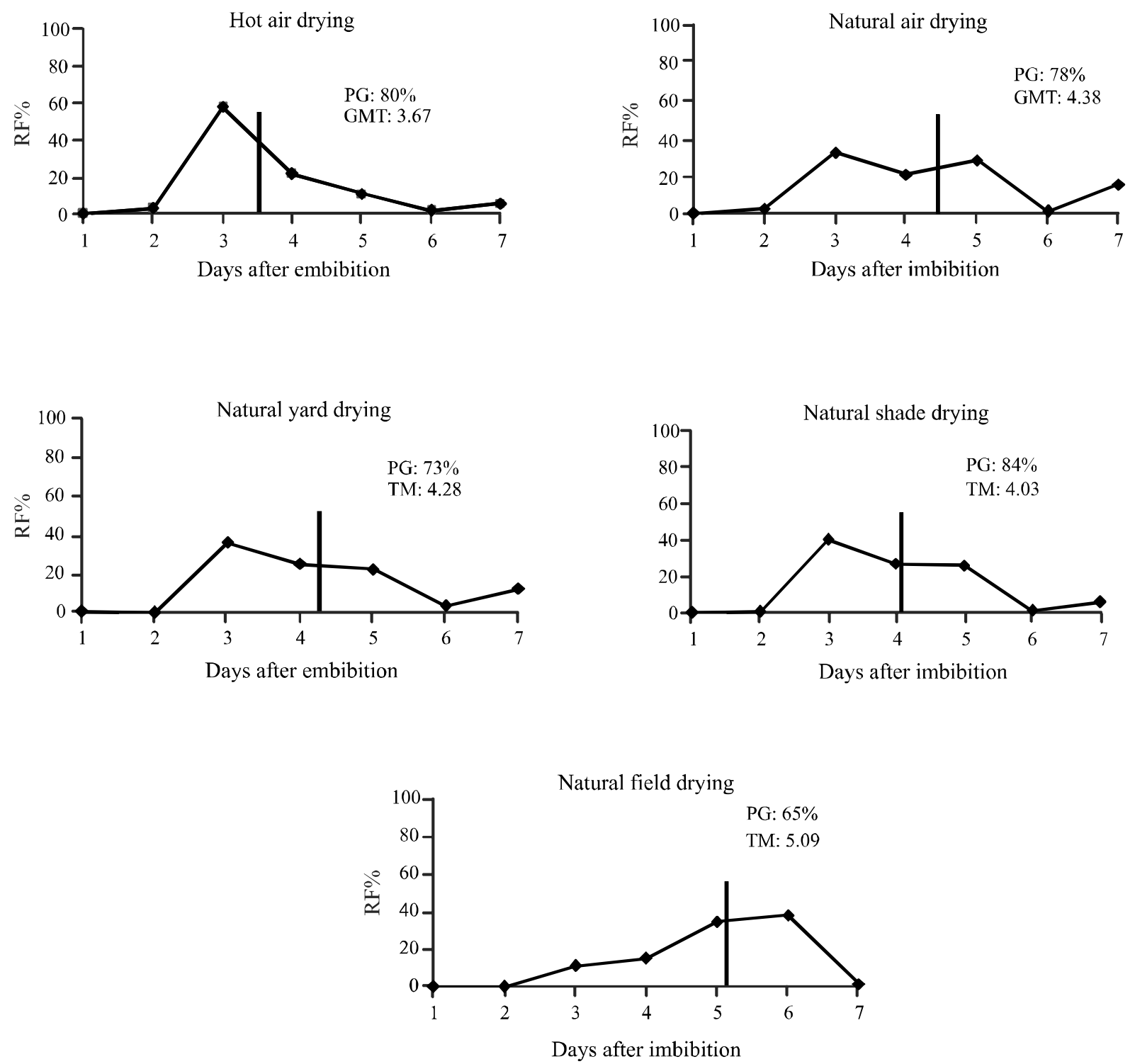

Table 5 - Average values of electrical conductivity (EC), fatty acids (FA) and oil content (OC) in crambe seeds submitted to different drying conditions

\begin{tabular}{lccc}
\hline \multirow{2}{*}{ Treatment } & EC & FA & OC \\
\cline { 2 - 4 } & $\left(\mu \mathrm{S} \mathrm{cm}^{-1} \mathrm{~g}^{-1}\right)$ & $\left(\mathrm{ml} \mathrm{KOH} 0.1 \mathrm{~N} 100 \mathrm{~g}^{-1} \mathrm{DM}\right)$ & $22,12 \mathrm{c}$ \\
\hline Hot air drying & $479.55 \mathrm{~b}$ & $6,735 \mathrm{a}$ & $28.92 \mathrm{a}$ \\
Natural air drying & $482.85 \mathrm{~b}$ & $8,115 \mathrm{~b}$ & $24.43 \mathrm{cb}$ \\
Natural yard drying & $476.74 \mathrm{~b}$ & $9,112 \mathrm{~b}$ & $26,39 \mathrm{~b}$ \\
Natural shade drying & $473.76 \mathrm{~b}$ & $8,930 \mathrm{~b}$ & $29.68 \mathrm{a}$ \\
Natural field drying & $387.96 \mathrm{a}$ & $9,100 \mathrm{~b}$ & $(\%$ \\
\hline
\end{tabular}

*Means followed by the same letter do not differ at the $5 \%$ level of significance by the t-test. 
contents were obtained with the methods of plant drying and natural air drying (Table 5), while the lowest levels were obtained with artificial drying with hot air. According Donadon et al. (2013) temperatures above $45{ }^{\circ} \mathrm{C}$ cause a change of the oil drops in the cytoplasm of the cotyledons cells in crambe seeds.

\section{CONCLUSIONS}

1. Artificial drying with hot air is the preferred method for reducing water contents of crambe seed. Furthermore maintains the seed physiological quality;

2. Despite taking a long time, natural shade drying is feasible for crambe seeds.

\section{REFERENCES}

AHRENS, D. C.; LOLLATO, M. A. Qualidade de semente de feijão e velocidade de secagem ao sol e em secador de fluxo contínuo. Informativo ABRATES, v. 5, n. 2, p. 52, 1995.

AMERICAN ASSOCIATION OF CEREAL CHEMISTS. Approved methods of the AACC. 8 th ed. Saint Paul: AACC, 1995. Paginação irregular.

BAKER, K. D.; PAULSEN, M. R.; VAN-ZWEDEN, J. Hibrid and drying rate effects on seed corn viability. Transactions of the ASAE, v. 34, n. 2, p. 499-506, 1991.

BIAGgIONI, M. A. M.; BARROS, R. E. Teste de acidez graxa como índice de qualidade em arroz. Ciência e Agrotecnologia, v. 30, n. 4, p. 679-684. 2006.

BRASIL. Ministério da Agricultura e da Reforma Agrária. Regras para análise de sementes. Brasília, DF: SNDA: DNDV: CLAV, 2009. 398 p.

CARVALHO, D. B.; CARVALHO, R. I. N. Qualidade fisiológica de sementes de guanxuma em influência do envelhecimento acelerado e da luz. Acta Scientiarum. Agronomy, v. 31, n. 3, p. 489-494, 2009.

CARVALHO, N. M.; NAKAGAWA, J. Sementes: ciência, tecnologia e produção. 5. ed. Jaboticabal: Funep, 2012. 590 p.

COSTA, L. M. et al. Storage of crambe fruit subjected to different drying conditions. African Journal of Agricultural Research, v. 47, n.7, p. 6274-6280, 2012a.

COSTA, L. M. et al. The influence of drying on the physiological quality of crambe fruits. Acta Scientiarum. Agronomy, v. 34, n. 2, p. 213-218, 2012 b.

DONADON, J. R. et al. Effect of hot air drying on ultrastructure of crambe seeds. Drying Technology, v. 31, p. 269-276, 2013.

EICHELBERGER, L. et al. Efeito do retardamento da secagem na qualidade fisiológica de sementes armazenadas de azevém anual. Pesquisa Agropecuária Brasileira, v. 38, n. 5, p. 643650, 2003.

FRANKE, L. B.; TORRES, M. A. P.; LOPES, R. R. Performance of different drying methods and their effects on the physiological quality of grain sorghum seeds ( $S$. bicolor (L.) Moench). Revista Brasileira de Sementes, v. 30, n. 3, p. 177-184, 2008.

GARCIA, D. C. et al. A secagem de sementes. Ciência Rural, v. 34, n. 2, p. 603-608, 2004.

JOSÉ, S. C. B. R. et al. Características físicas do pericarpo de sementes de milho associadas com tolerância à alta temperatura de secagem. Revista Brasileira de Sementes, v. 27, p. 125-131, 2005.

LABOURIAU, L. G. A germinação das sementes. Washington: Secretaria Geral da Organização dos Estados Americanos, 1983. 174 p.

MAGUIRE, J. D. Speeds of germination-aid selection and evaluation for seedling emergence and vigor. Crop Science, v. 2, p. 176-177, 1962.

MASETTO, T. E. et al. Qualidade fisiológica e sanitária de sementes de crambe produzidas no estado de mato grosso do sul. Revista Brasileira de Oleaginosas e Fibrosas, v. 13, n. 3, p. 107-11, 2009.

MASETTO, T. L. et al. Potencial hídrico do substrato e teor de água das sementes na germinação do crambe. Revista Brasileira de Sementes, v. 33, n. 3, p. 511-519, 2011.

MIRANDA, L. C.; SILVA, W. R. da; CAVARIANI, C. Secagem de sementes de soja em silo com distribuição radial do fluxo de ar. I. Monitoramento físico. Pesquisa Agropecuária Brasileira, v. 34, n. 11, p. 2097-2108, 1999.

NASSIF, S. M. L.; PEREZ, S. C. J. G. Efeito da temperatura na germinação de sementes de amendoim do campo (PterogynenitensTul.). Revista Brasileira de Sementes, v. 22, n. 1, p.1-6, 2000.

OLIVA, A. C. E.; BIAGNONI, M. A. M.; CAVARIANI, C. Efeito imediato do método de secagem na qualidade de sementes de crambe. Energia na Agricultura, v. 27, n. 3, p. 16-30, 2012.

PITOL, C. Cultura do crambe. In: FUNDAÇÃO MS. Tecnologia e produção: milho safrinha e culturas de inverno. Maracaju, MS, 2008. p. 85-88.

RESENDE, O. et al. Adzuki beans (Vigna angularis) seed quality under several drying conditions. Ciência e Tecnologia dos Alimentos, v. 32, n. 1, p. 151-155, 2012

ROSA, S. D. V. F. et al. Enzimas removedoras de radicais livres e proteínas LEA associadas à tolerância de sementes de milho à alta temperatura de secagem. Revista Brasileira de Sementes, v. 27, n. 2, p. 91-101, 2005.

SIRISOMBOON, P.; KITCHAIYA, P. Physical properties of Jatropha curcas L. kernels after heat treatments. Biosystems Engineering, v. 102, n. 2, p. 244-250, 2009. 
SOUZA, A. V. D. et al. Caracterização química de sementes e tortas de pinhao-manso, nabo-forrageiro e crambe. Pesquisa Agropecuária Brasileira, v. 44, n. 10, p. 13281335. 2009.

ULLMANN, R. et al. Qualidade das sementes de pinhão manso submetidas à secagem artificial. Revista Ciência Agronômica, v. 41, n. 3, p. 442-447, 2010.

VIEIRA, R. D. Teste de condutividade elétrica. In: VIEIRA, R. D.; CARVALHO, N. M. (Coord.) Testes de vigor em sementes. Jaboticabal: Funep, 1994. p. 103-132.
VIEIRA, R. D.; KRZYZANOWSKI, F. C. Teste decondutividade elétrica. In: KRZYZANOWSKI, F. C.;VIEIRA, R. D.; FRANÇA NETO, J. B. (Ed.). Vigor desementes: conceitos e testes. Londrina: Abrates, 1999. p. 1-26.

ZONTA, J. B. et al. Diferentes tipos de secagem: efeitos na qualidade fisiológica de sementes de pinhão manso. Revista Brasileira de Sementes, v. 33, n. 4, p. 721-731, 2011.

ZUCHI, J. et al. Retardamento de colheita, método de secagem e qualidade de sementes de mamona. Revista Brasileira de Sementes, v. 31, p. 9-15, 2009. 